\title{
DNA polymerase $\lambda$ - a novel DNA repair enzyme in higher plant genome
}

\author{
Sujit Roy ${ }^{\otimes}$
}

\begin{abstract}
DNA polymerase lambda (Pol $\lambda$ ) is a novel family X DNA polymerase which has been shown to play key role in nuclear DNA repair and meiotic recombination. Recent studies in mammals support function of this enzyme in base excision repair in response to oxidative DNA damage. However, in plants the biological function of Pol $\lambda$ in oxidative stress response is still largely unknown. This review will survey recent advances in our understanding of role of Pol $\lambda$ in repair of oxidative DNA damages and its possible potential involvement in plant's base excision repair (BER) pathway in response to oxidative stress.
\end{abstract}

Keywords: Arabidopsis thaliana; oxidant stress; plant growth.

Plant DNA is under continuous threat from endogenous and environmental genotoxic factors

During their lifetime, plants, with the obligatory dependence on sunlight for energy, are constantly exposed to various environmental stresses and genotoxic agents including UV-B, ozone, desiccation and rehydration, high soil salinity, air and soil pollutants including heavy metals and other pollutants, as well as metabolic byproducts. These agents cause variety of DNA damages including DNA

Received: 14 May 2014 / Accepted revised version: 9 July 2014 / Published online: 10 August 2014

(C) Horizon e-Publishing Group

CITATION

Roy, S. (2014). DNA polymerase $\lambda$ - a novel DNA repair enzyme in higher plant genome. Plant Science Today, 1(3), 140-146. http://dx.doi.org/10.14719/pst.2014.1.3.59

\section{AUTHOR'S AFFILIATION}

Protein Chemistry laboratory, Department of Chemistry, Bose Institute, 93/1 Acharya Prafulla Chandra Road, Kolkata 700 009, West Bengal, India.

\section{CORRESPONDENCE}

Sujit Roy, Phone: 910332303 1152, Fax: 910332350 6790, Email: sujitroy2006@gmail.com base oxidation and alkylation, formation of pyrimidine dimers and abasic sites, single and double strand breaks (SSBs and DSBs), DNA inter-strand cross links and therefore threaten the integrity of plant genome. The irreversible DNA damages affect plant growth and development, reproduction and finally crop productivity (Roy, Roy Choudhury, \& Das, 2013a; Roy, Roy Choudhury, Sengupta, \& Das, 2013b; Tuteja, Ahmad, Panda, \& Tuteja, 2009). In order to ensure genome stability and maintain normal growth, development and productivity, plants have evolved a powerful and extensive array of rapid cellular responses that lead to cell-cycle arrest, recruitment of DNA repair proteins to the site of damage and repair of DNA damage (Fig. 1) together with additional coordinated responses such as stress neutralization, shedding of affected tissues, and renewal of tissue growth.

\section{Oxidative stress and reactive oxygen species}

Oxidative damage is one of the major stresses in plants (Hodges, Andrews, Johnson, \& Hamilton, 1997), which induces the production of reactive oxygen species (ROS) and also other highly reactive free radicals (Wise, \& Naylor, 1987). The reactive oxygen species, generated either endogenously by oxidative electron transport in mitochondria and chloroplast, or exogenously in response to abiotic and biotic stresses can affect almost all the cellular components and induces multiple forms of DNA damages, and thus activates genotoxic stress. ROS react with DNA and generate oxidized form of bases, some of which have extremely mutagenic effects. In mammals, 7,8-dihydro-8-oxoguanine (8-oxo-G) and 1,2-dihydro-2-oxoadenine (2-OH-A) are most commonly generated oxidized bases when ROS attack DNA (Collins, 1999). Occurrence of 8-oxo-G in the replicating strand does not significantly affect DNA replication however it promotes mis-incorporation of nucleotides such as high frequency of incorporation of $A$ against 8-oxo-G. In contrast, existence of 2-OH-A on the replicating strand during replication phase strongly block the progression of the replication fork by the replicative DNA polymerases, resulting in single-stranded (ss) DNA due to separation 


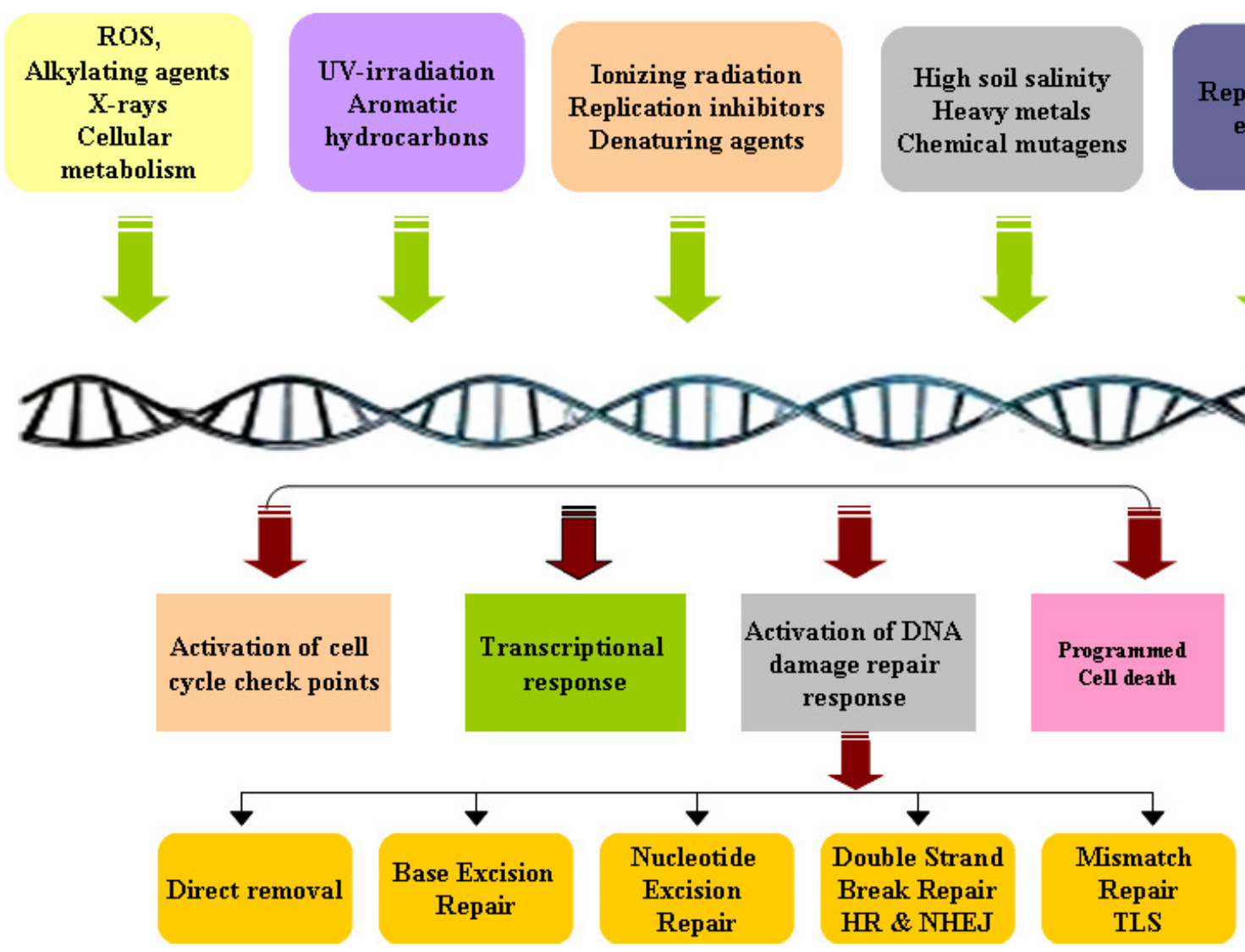

Fig. 1. DNA damage signalling in plants. Plant DNA is under continuous assault from environmental factors like UV and ionizing radiation, high salinity, chemical mutagens, and free radicals or alkylating agents generated by endogenous processes. The cellular response to damage involve four coordinated steps - activation of a cell cycle checkpoint function, initiation of transcriptional response, induction of DNA repair and initiation of programme cell death.

between DNA unwinding and synthesis. ssDNA acts as a common DNA-damage intermediate recognized by complexes associated with ATM (ataxia telangiectasia mutated) and ATR (ATM and Rad3-related) protein kinases. ATR kinases, in particular activates cell-cycle check-point function by phosphorylation of the downstream target Chk1 (check point kinase) which subsequently inhibits activation of origin and blocks the $\mathrm{S}$ to G2 phase transition, delaying cell cycle progression (Barone et al., 2007).

\section{The Base Excision Repair pathway removes oxidized bases from DNA}

In human cells, the oxidized bases in the DNA are mainly repaired via base excision repair (BER) which involves the removal of the damaged base by a specific glycosylase, producing an abasic site, which is subsequently processed by the step-wise action of the APE1 endonuclease (Apurinic/apyrimidinic endonuclease), Pol $\beta$ and XRCC1-DNA ligase 1 complex to finally seal the nick (Singhal, Prasad, \& Wilson, 1995). However, prolonged replication stress due to inefficient BER activity induces the formation of other potentially harmful DNA intermediates including double strand breaks, in addition to single strand breaks. In human cells, a specialized repair pathway called trans lesion synthesis (TLS) has been shown to be activated in response to prolonged replication block via checkpoint activation which recruits specialized DNA Pols, mainly members of family X and Y polymerases which are capable to bypass the lesion to resume replication. On the other hand the double stand breaks (DSBs) generated by stalled replication fork or delayed $\mathrm{BER}$, are repaired via homologous recombination (HR) (during the $S$ phase of cell cycle only) and non-homologous end joining (NHEJ) mechanisms.

\section{DNA polymerase $\boldsymbol{\lambda}$ - a novel X family DNA polymerase}

DNA polymerase $\lambda(\mathrm{Pol} \lambda)$ is a family $\mathrm{X}$ member and is widespread among higher eukaryotes, both in animals and plants. Mammalian Pol $\lambda$ is an exonuclease-deficient, 575-amino acid single polypeptide DNA polymerase (García-Diaz et al., 2000, 2002; Ramadan, Shevelev, \& Hübscher, 2004) which has been found to share high degree of sequence homology with mammalian Pol $\beta$ (32\% 
amino acid identity). In mammals, a plethora of studies have demonstrated the involvement of Pol $\lambda$ in all the three major repair pathways including BER (Garcia-Ortiz, Ariza, \& Roldan-Arjona, 2001), NHEJ (Lee et al., 2004), and TLS (Picher \& Blanco, 2007; Maga et al., 2007; Hübscher \& Maga, 2011). Earlier studies have established a role of mammalian Pol $\lambda$ in TLS for error-free bypass of 2-OH-A and 8-oxo-G lesions in response to oxidative DNA damages (Picher \& Blanco, 2007; Crespan, Hübscher, \& Maga, 2007). More recent studies have indicated that knockdown of Pol $\lambda$ ceases replication fork progression and stimulates the ATR/Chk1-mediated $S$ phase checkpoint function, resulting in delay of $S$ phase progression in various human cancer cell lines. Interesting, knockdown of Pol $\beta$, the closest homologue of mammalian Pol $\lambda$, failed to activate such response. Together, these observations indicate direct functional involvement of Pol $\lambda$ in cellular response to DNA damage in the context of oxidative DNA damage and replication stress (Zucca et al., 2013).

\section{Pol $\lambda$ interacts with key cell cycle regulatory components, repair and replication associated proteins}

Multiple lines of evidence have demonstrated interactions of Pol $\lambda$ with the key cell cycle regulatory proteins. In vitro and in vivo studies established interaction of human Pol $\lambda$ with cyclin-dependent kinase 2 (CDK2), a key component for G1/S transition (CDK2/cyclin E) and S-phase progression (CDK2/cyclin A) of the cell cycle. Phosphorylation at Thr 553 in human Pol $\lambda$ was found to be crucial for maintaining Pol $\lambda$ stability during cell cycle progression in the late S and G2 phases, preventing it from being degraded via proteasomal pathway by ubiquitination and allowing the time for repair during and after S phases (Wimmer, Ferrari, Hunziker, \& Hübscher, 2008). Recent studies have established the functional and physical interaction of human Pol $\lambda$ with MutYH (MutY glycosylase homologue) in a mismatch repair pathway for the error-free bypass of 8-oxo-G lesions in the DNA. The interaction was found to be regulated by a delicately balanced phosphorylation and ubiquitination of Pol $\lambda$, governing the stabilization of protein in late $S$ phase and its recruitment to chromatin into active 8-oxo-G repair complexes. Interestingly, Pol $\lambda$ not involved in 8-oxo-G repair, have been shown to be subjected for proteasomal degradation (Markkanen, van Loon, Ferrari, Parsons, Dianov, \& Hübscher, 2012). More recent research have demonstrated that Pol $\lambda$ is functionally associated with $S$ phase DNA damage response machinery in mammalian cancer cell lines in order to protect cells from oxidative DNA damage (Zucca et al., 2013).

In plants, although information is still limited on the post-translational regulation of Pol $\lambda$, phospho-proteomic analyses have identified several potential phosphorylation sites in the $\mathrm{N}$ terminus Ser/Pro rich domain in Arabidopsis
Pol $\lambda$, indicating the possibility of in vivo phosphorylation of Pol $\lambda$ by cdk/cyclin complexes like cdk5 and cdc2 during cell cycle progression (unpublished data). In addition, Arabidopsis and rice Pol $\lambda$ possess a highly conserved PIP box (PCNA binding domain) QK/RL/IGLKY/FF. The PIP box was found to regulate the interaction of Pol $\lambda$ with PCNA2 (proliferating cell nuclear antigen 2) for enhancing the fidelity and efficiency of translesion synthesis in oxidative DNA damage repair in Arabidopsis (Amoroso et al., 2011). Furthermore, in silico analyses (http://smart.embl-heidelberg.de/) have predicted possible interactions of Arabidopsis Pol $\lambda$ with additional DNA repair responsive proteins including the BER pathway proteins Pol $\delta$ and DNA ligase 1 (Roy et al., 2013a). Interestingly, Pol $\lambda$ contains a highly conserved $N$ terminus BRCT (BRCA1 C terminus) domain which is predominantly found in proteins involved in cell cycle checkpoint functions in response to DNA damage and known to mediate protein-protein interactions. Our recent results in Arabidopsis have shown that Pol $\lambda$ interacts directly with XRCC4 (X-ray repair cross-complementing protein 4) and DNA ligase4 via its $\mathrm{N}$ terminus BRCT domain during repair of high salinity and DNA cross linking agent induced DSBs through NHEJ pathway (Roy et al., 2013b). Together, these observations suggest that Pol $\lambda$ interacts with various crucial regulatory partners, which appear to govern the stability and activity of Pol $\lambda$ and its recruitment to the site of DNA damage.

\section{Is Pol $\lambda$ involved in plant's BER?}

In comparison to plants, the understanding of the mechanism of BER, one of the major pathways of repair of oxidative DNA damages, is far more advanced in mammals, yeast and Escherichia coli. However, studies in plants mainly involving Arabidopsis have identified structural and/or functional homologs of most of the BER proteins in plant genome (Britt, 2002; García-Ortiz et al., 2001; Kimura \& Sakaguchi, 2006; Roldan-Arjona \& Ariza, 2009). In plants, the general knowledge about Pol $\lambda$ structure and functions is still limited. Genome-wide sequence analyses have identified Pol $\lambda$ as the only member of family X DNA Pols in plants and therefore, appear to substitute for the function of Pol $\beta$ to play a key role in nuclear DNA damage repair and recombination. Similar to human Pol $\lambda$, Arabidopsis Pol $\lambda$ (AtPol $\lambda$ ) is comprising of two major domains, the $\mathrm{N}$-terminal domain and the C-terminal highly conserved Pol X motif which is the active site for polymerase activity. The N-terminal part contains a nuclear localization signal (NLS), a BRCT (breast cancer susceptibility C-terminus) module, which acts as the site for protein-protein and protein-DNA interactions, and a Ser-Pro-rich domain which acts as a suppressor of DNA polymerase activity and also serves as target site for post-translational modification (Fig. 2A). AtPol $\lambda$ showed $\sim 39 \%$ identity and $\sim 57 \%$ similarity in amino acid sequence with human Pol $\lambda$. Amino acid sequence 
A

\begin{tabular}{|c|c|c|c|c|c|c|c|}
\hline \multicolumn{2}{|l|}{1} & \multicolumn{5}{|c|}{ — PolX domain } & 529 \\
\hline 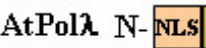 & BRCT & Ser-Pro-rich & 8-kDa & Finger & Palm & Thuml & $\mathrm{C}$ \\
\hline \multicolumn{8}{|c|}{ (13 aa) $\vdash 96 \mathrm{aa} \dashv \longmapsto 89 \mathrm{aa} \dashv \longmapsto$} \\
\hline 1 & & & & & & & 575 \\
\hline HsPold N-NMS & BRCT & Ser-Pro-rich & 8-kI & \begin{tabular}{l|l} 
& Finger \\
\end{tabular} & Pal & & humb -C \\
\hline
\end{tabular}

B

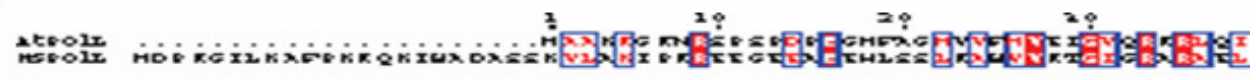

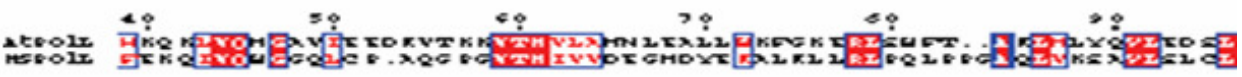

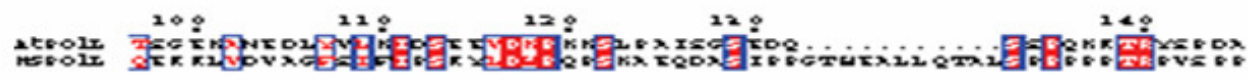

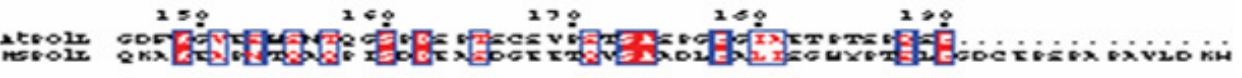

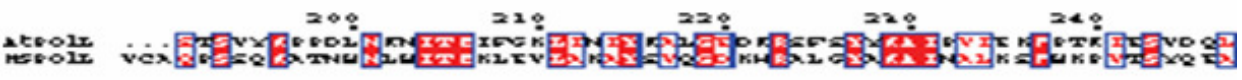

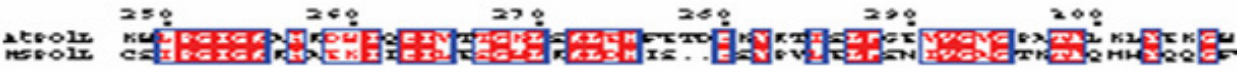

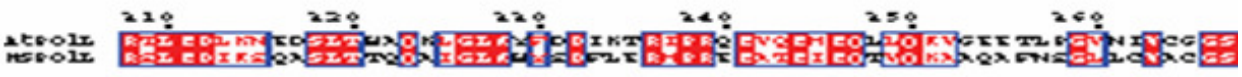

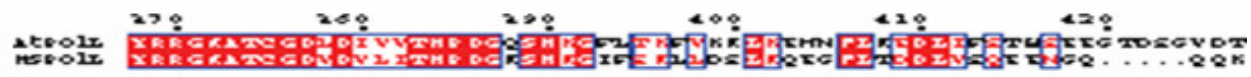

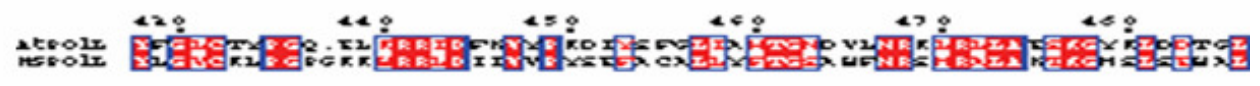

terol1

Fig. 2. Structural similarities between human and Arabidopsis Pol $\lambda$. A. Schematic representation of the domain structures of Arabidopsis and human Pol $\lambda$ (AtPol $\lambda$ and HSPol $\lambda$ ). The amino acid numbers for the proteins and the related sub-domain features are indicated. The GenBank accession numbers are ADM33939 (AtPol $\lambda$ ) and NP_001167555 (human Pol $\lambda$ ), respectively. B. Alignment of human Pol $\lambda$ and AtPol $\lambda$ amino acid sequences using the ClustalW program (Thompson, Higgins, \&

Gibson, 1994). The image was prepared with Espript (Gouet, Courcelle, Stuart, \& Metoz, 1999). Residues that are completely conserved are colored red and highlighted with a blue box. The numbering shown above the alignment represents that of Arabidopsis Pol $\lambda$.

alignment of human Pol $\lambda$ and AtPol $\lambda$ showed a high degree of amino acid residue conservation at the Pol $\mathrm{X}$ domain (Fig. 2B) (Roy, Roy Choudhury, Singh, \& Das,
2011). In addition, as like mammalian Pol $\lambda$, the C-terminal Pol X domain comprises of an N-terminal $8 \mathrm{kDa}$ domain, unique to family $\mathrm{X}$ Pols and a polymerase domain, 
organized in fingers, palm and the thumb sub-domains which are common to all polymerases (Roy et al., 2013b).

Previous studies have established key role of Pol $\lambda$ in diverse repair pathways in plant genome, including nucleotide excision repair (NER) for removal of UV-B induced photoproducts (Roy et al., 2011) and error-free translesion DNA synthesis in response to oxidative DNA damage in Arabidopsis (Amoroso et al., 2011). We have characterized the transcriptional regulation of Pol $\lambda$ gene in Arabidopsis (AtPol $\lambda$, At1G10520) under diurnal conditions (Roy, Roy Choudhury, Singh, \& Das, 2012). Our recent studies have demonstrated involvement of Pol $\lambda$ in the repair of high salinity and DNA cross-linking agent induced DSBs via the NHEJ pathway in Arabidopsis (Roy et al., 2013b). Therefore multiple evidences support that Pol $\lambda$ acts as key player in various crucial DNA repair pathways in plant genome.

During the lifecycle plants undergo considerable periods of quiescence when the plant embryo is maintained within the dormant seed (Sallon et al., 2008). Dehydration during storage and subsequent water imbibitions of dry seeds during germination was found to be associated with high levels of oxidative stress which cause significant damage to the integrity of the genome of seed embryo. This is commonly found when seeds are stored under unfavourable conditions like high temperatures and moisture contents (Kranner, Minibayeva, Beckett, \& Seal, 2010). Loss of seed viability in storage conditions is strongly linked with various forms DNA damage in seed embryo including single and double strand breaks and even chromosomal breakages and aberrant chromosomes (Waterworth, Drury, Bray, \& West, 2011). However information on the repair of oxidative DNA lesions in seed embryo via BER activity during germination is very limited. Recent studies have shown that Arabidopsis cell extracts contain the enzymatic machinery required for uracil and abasic (AP) sites repair via short patch BER pathway (Cordoba-Canero, Morales-Ruiz, Roldan-Arjona, \& Ariza, 2009). Overexpression of a DNA glycosylase/AP lyase, a BER pathway component, was found to enhance seed longevity and abiotic stress tolerance in Arabidopsis (Chen et al., 2012). In mammals, studies with extracts from mouse embryonic fibroblasts have indicated that mammalian Pol $\lambda$ possesses dRP lyase (5'-deoxyribose phosphate lyase) activity in vitro, suggesting involvement of Pol $\lambda$ in BER. This activity has been found to be associated with the 8-kDa domain at the C-terminal Pol X region of the protein (García-Díaz, Bebenek, Kunkel, \& Blanco, 2001). Previously, biochemical evidences have indicated that rice Pol $\lambda$ possess the dRP lyase activity (a key feature for repair DNA polymerases involved in BER), indicating possible role of Pol $\lambda$ in the gap-filling step in plant's BER pathway (Uchiyama, Kimura, Yamamoto, Ishibashi, \& Sakaguchi, 2004). However, unlike mammalian its counterpart, role of Pol $\lambda$ in BER pathway has not been well characterized in plants at the structure-function level. Therefore, unveiling the mechanisms of BER at the structural, molecular and genetic level in the context of role of Pol $\lambda$ will be further interesting for understanding the biological function of this sole member of family X DNA polymerase in relation to plant growth and productivity.

\section{Outlook}

Significant progress has been achieved in the last few years in understanding the mechanisms of plant DNA repair and recombination. The main pathways of repair are becoming well characterized. The mechanisms by which plant cells respond to environmental and genotoxic stress, including the key early steps of damage detection, transfer of signal and activation of cell cycle checkpoint functions, have just begun to unveil. Future challenges will be further expanding knowledge on the fundamental DNA repair functions which are active in plants, to provide the way towards interesting biotechnological applications focused at improving various stress tolerance in crop plants. Significant research in this area in future will provide meaningful insight about how plants survive under stresses and possible strategies to improve crop growth and productivity in the context of understanding the long-term impacts of adverse environmental conditions on plant genomes.

\section{Acknowledgement}

This work was supported by the CSIR Pool Scientist's scheme (Ref No. 13(8611-A)/2013-Pool) to SR. I sincerely thank Prof. K.P. Das, Dept. of Chemistry, Bose Institute, Kolkata, India and Dr. Swarup Roy Choudhury, Donald Danforth Plant Science Center, St. Louis, Missouri, for the critical reading and corrections on the article. I apologize to all authors whose work was not cited due to the length limitations.

\section{References}

Amoroso, A., Concia, L., Maggio, C., Raynaud, C., Bergounioux, C., Crespan, E., ... Maga, G. (2011). Oxidative DNA damage bypass in Arabidopsis thaliana requires DNA polymerase $\lambda$ and proliferating cell nuclear antigen 2. Plant Cell, 23, 806-822 http://dx.doi.org/10.1105/tpc.110.081455 PMid:21325140 PMCid:PMC3077771.

Barone, F., McCulloch, S. D., Macpherson, P., Maga, G., Yamada, M., Nohmi, T., ... Bignami, M. (2007). Replication of 2-hydroxyadenine-containing DNA and recognition by human MutSalpha. DNA Repair, 6, 355-366 http://dx.doi.org/10.1016/j.dnarep.2006.11.002 PMid:17188944 PMCid:PMC2111060.

Britt, A. B. (2002). Repair of damaged bases. In The Arabidopsis Book (Somerville, C. and Meyerowitz, E.M., eds). Rockville, MD: American Society of Plant Biologists, http://dx.doi.org/10.1111/tab.0005

Chen, H., Chu, P., Zhou, Y., Li, Y., Liu, J., Ding, Y., ... \& Huang, S. (2012). Overexpression of AtOGG1, a DNA glycosylase/AP lyase, enhances seed longevity and abiotic stress tolerance in 
Arabidopsis. Journal of Experimental Botany, 63, 4107-21 http://dx.doi.org/10.1093/jxb/ers093 PMid:22473985.

Collins, A. R. (1999). Oxidative DNA damage, antioxidants, and cancer. Bioessays, 21, 238-246 http://dx.doi.org/10.1002/(SICI)1521-1878(199903)21:3< 238::AID-BIES8>3.0.CO;2-3

Cordoba-Canero, D., Morales-Ruiz, T., Roldan-Arjona, T., \& Ariza, R. R. (2009). Single-nucleotide and long-patch base excision repair of DNA damage in plants. Plant Journal, 60, 716-728 http://dx.doi.org/10.1111/j.1365-313X.2009.03994.x PMid:19682284 PMCid:PMC2954439.

Crespan, E., Hübscher, U., \& Maga, G. (2007). Error-free bypass of 2-hydroxyadenine by human DNA polymerase lambda with Proliferating Cell Nuclear Antigen and Replication Protein A in different sequence contexts. Nucleic Acids Research, 35, 5173-5181. http://dx.doi.org/10.1093/nar/gkm568 PMid:17666409 PMCid:PMC1976453.

García-Díaz, M., Bebenek, K., Kunkel, T. A., \& Blanco, L. (2001). Identification of an intrinsic 5'-deoxyribose-5-phosphate lyase activity in human DNA polymerase lambda: a possible role in base excision repair. Journal of Biological Chemistry, 276, 34659-63. http://dx.doi.org/10.1074/jbc.M106336200 PMid:11457865.

García-Díaz, M., Bebenek, K., Sabariegos, R., Domínguez, O., Rodríguez, J., Kirchhoff, T., ... Blanco, L. (2002). DNA Polymerase Lambda, a Novel DNA Repair Enzyme in Human Cells. Journal of Biological Chemistry, 277, 13184-13191. http://dx.doi.org/10.1074/jbc.M111601200 PMid:11821417.

García-Díaz, M., Domínguez, O., López-Fernández, L. A., Laín de Lera, T., Saníger, M. L., Ruiz, F. J., ... Blanco, L. (2000). DNA polymerase lambda (Pol $\lambda$ ), a novel eukaryotic DNA polymerase with a potential role in meiosis. Journal of Molecular Biology, 301, 851-867. http://dx.doi.org/10.1006/jmbi.2000.4005 PMid:10966791.

Garcia-Ortiz, M. V., Ariza, R. R., \& Roldan-Arjona, T. (2001). An OGG1 orthologue encoding a functional 8-oxoguanine DNA glycosylase/lyase in Arabidopsis thaliana. Plant Molecular Biology, 47, 795-804. PMid:11785940. http://dx.doi.org/10.1023/A:1013644026132

Gouet, P., Courcelle, E., Stuart, D., \& Metoz, F. (1999). ESPript: analysis of multiple sequence alignments in PostScript. Bioinformatics, $\quad 15, \quad 305-308 . \quad$ PMid:10320398. http://dx.doi.org/10.1093/bioinformatics/15.4.305

Hodges, D. M., Andrews, C. J., Johnson, D. A., \& Hamilton, R. I. (1997) .Antioxidant enzyme and compound responses to chilling stress and their combining abilities in differentially sensitive maize hybrids. Crop Science, 37, 857-863. http://dx.doi.org/10.2135/cropsci1997.0011183X0037000 30027x.

Hübscher, U., \& Maga, G. (2011). DNA replication and repair bypass machines. Current Opinion in Chemical Biology, 15, 627-635. http://dx.doi.org/10.1016/i.cbpa.2011.08.009 PMid:21889903.

Kimura, S., \& Sakaguchi, K. (2006). DNA repair in plants. Chemical Reviews, 106, 753-766. PMid:16464023 http://dx.doi.org/10.1021/cr040482n
Kranner, I., Minibayeva, F. V., Beckett, R. P., \& Seal, C. E. (2010). What is stress? Concepts, definitions and applications in seed science. New Phytologist, 188, 655-673. http://dx.doi.org/10.1111/j.1469-8137.2010.03461.x PMid:20854396.

Lee, J. W., Blanco, L., Zhou, T., Garcia-Diaz, M., Bebenek, K., Kunkel, T. A., ... Povirk, L. F. (2004). Implication of DNA polymerase lambda in alignment-based gap filling for nonhomologous DNA end joining in human nuclear extracts. Journal of Biological Chemistry, 279, 805-811. http://dx.doi.org/10.1074/ibc.M307913200 PMid:14561766.

Maga, G., Villani, G., Crespan, E., Wimmer, U., Ferrari, E., Bertocci, B., \& Hübscher, U. (2007). 8-oxo-guanine bypass by human DNA polymerases in the presence of auxiliary proteins. Nature, 447, 606-608. http://dx.doi.org/10.1038/nature05843 PMid:17507928.

Markkanen, E., van Loon, B., Ferrari, E., Parsons, J. L., Dianov, G. L., \& Hübscher, U. (2012). Regulation of oxidative DNA damage repair by DNA polymerase lambda and MutYH by cross-talk of phosphorylation and ubiquitination. Proceedings of National Academy of Sciences USA, 109, 437-442. http://dx.doi.org/10.1073/pnas.1110449109 PMid:22203964 PMCid:PMC3258598.

Picher, A. J., \& Blanco, L. (2007). Human DNA polymerase lambda is a proficient extender of primer ends paired to 7,8-dihydro-8-oxoguanine. DNA Repair, 6, 1749-1756. http://dx.doi.org/10.1016/j.dnarep.2007.06.007 PMid:17686665.

Ramadan, K., Shevelev, I., \& Hübscher, U. (2004). The DNA-polymerase-X family: controllers of DNA quality? Nature Reviews Molecular Cell Biology, 5, 1038-1043. http://dx.doi.org/10.1038/nrm1530 PMid:15573140

Roldan-Arjona, T., \& Ariza, R. R. (2009). Repair and tolerance of oxidative DNA damage in plants. Mutation Research, 681, 169-179. http://dx.doi.org/10.1016/j.mrrev.2008.07.003 PMid:18707020.

Roy, S., Roy Choudhury, S., Singh, S. K., \& Das, K. P. (2011). AtPol $\lambda$, a homolog of mammalian DNA polymerase $\lambda$ in Arabidopsis thaliana, is involved in the repair of UV-B induced DNA damage through the dark repair pathway. Plant Cell Physiology, 52, 448-467. PMid:21227935 http://dx.doi.org/10.1093/pcp/pcr002

Roy, S., Roy Choudhury, S., Singh, S. K., \& Das, K. P. (2012). Functional analysis of light-regulated promoter region of AtPol $\lambda$ gene. Planta, 235, 411-432. http://dx.doi.org/10.1007/s00425-011-1517-6 PMid:21947619.

Roy, S., Roy Choudhury, S., \& Das, K. P. (2013a). The interplay of DNA polymerase $\lambda$ in diverse DNA damage repair pathways in higher plant genome in response to environmental and genotoxic stress factors. Plant Signal Behaviour, 12/2012, $8(1)$.

Roy, S., Roy Choudhury, S., Sengupta, D. N., \& Das, K. P. (2013b). Involvement of AtPol $\lambda$ in repair of high salt and DNA cross linking agent induced double strand breaks in Arabidopsis thaliana. Plant Physiology, 162, 1195-1210. 
http://dx.doi.org/10.1104/pp.113.219022 PMid:23660835 PMCid:PMC3668049.

Sallon, S., Solowey, E., Cohen, Y., Korchinsky, R., Egli, M., Woodhatch, I., ... \& Kislev, M. (2008). Germination, genetics, and growth of an ancient date seed. Science, 320, 1464. http://dx.doi.org/10.1126/science.1153600 PMid:18556553.

Singhal, R. K., Prasad, R., \& Wilson, S. H. (1995). DNA polymerase beta conducts the gap-filling step in uracil-initiated base excision repair in a bovine testis nuclear extract. Journal of Biological Chemistry, 270, 949-957. http://dx.doi.org/10.1074/jbc.270.2.949 PMid:7822335.

Thompson, J., Higgins, D., \& Gibson, T. (1994). CLUSTAL W: improving the sensitivity of progressive multiple sequence alignment through sequence weighting, position-specific gap penalties and weight matrix choice. Nucleic Acids Research, 22, 4673-4680. http://dx.doi.org/10.1093/nar/22.22.4673 PMid:7984417 PMCid:PMC308517.

Tuteja, N., Ahmad, P., Panda, B. B., \& Tuteja, R. (2009). Genotoxic stress in plants: shedding light on DNA damage, repair and DNA repair helicases. Mutation Research, 681, 134-149. http://dx.doi.org/10.1016/i.mrrev.2008.06.004 PMid:18652913.

Uchiyama, Y., Kimura, S., Yamamoto, T., Ishibashi, T., \& Sakaguchi, K. (2004). Plant DNA polymerase lambda, a DNA repair enzyme that functions in plant meristematic and meiotic tissues. European Journal of Biochemistry, 271, 2799-2807. http://dx.doi.org/10.1111/j.1432-1033.2004.04214.x PMid:15206945.

Waterworth, W. M., Drury, G. E., Bray, C. M., \& West, C. E. (2011). Repairing breaks in the plant genome: the importance of keeping it together. New Phytologist, 192, 805-822. http://dx.doi.org/10.1111/j.1469-8137.2011.03926.x PMid:21988671.

Wimmer, U., Ferrari, E., Hunziker, P., \& Hübscher, U. (2008). Control of DNA polymerase $\lambda$ stability by phosphorylation and ubiquitination during the cell cycle. EMBO Reporter, 9, 1027-1033. http://dx.doi.org/10.1038/embor.2008.148 PMid:18688254 PMCid:PMC2572118.

Wise, R. R., \& Naylor, A. W. (1987). Chilling-enhanced photooxidation: The peroxidative destruction of lipids during chilling injury to photosynthesis and ultrastructure. Plant Physiology, 83, 272-277. http://dx.doi.org/10.1104/pp.83.2.272 PMid:16665235 PMCid:PMC1056347.

Zucca, E., Bertoletti, F., Wimmer, U., Ferrari, E., Mazzini, G., Khoronenkova, S., ... \& Maga, G. (2013). Silencing of human DNA polymerase $\lambda$ causes replication stress and is synthetically lethal with an impaired S phase checkpoint. Nucleic Acids Research, 41, 229-241. http://dx.doi.org/10.1093/nar/gks1016 PMid:23118481 PMCid:PMC3592438. 